\title{
Albanon
}

Revistë kulturore

\section{Përtej mitit për Normalen, vlera që i shërbejnë së tashmes}

\author{
Tomorr PLANGARICA
}

Shkolla Normale e Elbasanit është ndër ato institucione arsimore (gjithsesi jo të shumta), themelimi i së cilës u shoqërua njëherazi edhe me lindjen e mitit për të. Ndodhte ky asosacion fatlum, sepse ajo u konsiderua që në lindje si përmbushje e një dëshire që kishte dhjetëra vite që përvijohej e, për më tepër, e një shprese që rrokte jo thjesht hapësira të edukimit e arsimimit, por shumë më gjerë: të patriotizmit që duhej mëkuar, të intelektualizmit që duhej kultivuar, të shkencës që duhej themeluar e dijes që duhej përhapur në mjedise shumë më të gjera se në një institucion, një qytet a një trevë. Dhe kjo dëshirë, ky entuziazëm motivues veçse u materializua nëpërmjet breza pedagogësh e studentësh të atij institucioni; e për pasojë, veçse i përforcoi e zgjeroi përmasat e mitit për të.

Dhe në fakt, Normalja ishte një institucion që, qysh prej krijimit të tij më 1909-ën e për disa dhjetëvjeçarë në gjysmën e parë të shekullit XX, i tejkaloi përmasat e një shkolle të mesme. Në kushtet e kohës, Normalja u përvijua si institucion që synoi të vinte bazat e intelektualizmit dhe të profesionalizmit te një kontigjent nxënësish të ardhur nga tërë hapësira kombëtare; ishte një institucion që kishte përfaqësuesit e tij në shumë prej majave të mendimit psiko-pedagogjik shqiptar të kohës; një institucion që përballoi me sukses problemet e hartimit të teksteve dhe kontribuoi në mendimin tekstologjik; një institucion në të cilin herë kolektivisht, e herë individualisht, u hartuan programet mësimore për cikle të caktuara shkollimi dhe zbërthimet metodike të tyre; një institucion me një organ botues për vite me radhë; një institucion që përfaqësohet në botimet e viteve 20-40 të shekullit XX me mbi 30 firma studiuesish; një institucion që inicioi në shtyp mbi 100 firma studentësh, prej të cilëve u afirmuan më tej mbi 30; një institucion që mundësoi një 
plejadë të tërë intelektualësh që trajtuan apo u prirën drejt zgjidhjes së shumë prej problemeve mbizotëruese të mendimit pedagogjik, psikologjik apo të aspekteve të zbatuara të shkencave të tilla si gjuhësia, letërsia, historia, matematika etj.

Rastet kur emri, jeta, veprimtaria, kontributet dhe vlera e një institucioni arsimor shndërrohen në ndërgjegjen e një komuniteti, një populli, një kombi në mite janë fatlume dhe kjo mënyrë e perceptimit të vlerave edhe në kohët moderne vetëm se ia shton ngarkesat pozitive dhe shkëlqimin historisë së institucionit përkatës, e bën atë veprues edhe në epoka ku shumëçka ka ndryshuar, por fryma për zhvillim, përshpejtimi i ritmeve për të arritur kuota sa më të larta të së ardhmes janë të pranishme në vazhdimësi.

"Mitet tona aktuale drejtojnë njerëzit për t’u përgatitur në një luftim..." vëren G. Sorel-i. Si të tilla, mitet që mveshin me një aureolë shenjtërimi dhe sublimiteti institucionet, veçse na shtyjnë më tej drejt njohjes së tyre dhe mesazheve që ato emetojnë, për të na ndihmuar për të ardhmen.

$\mathrm{Një} \mathrm{ndër} \mathrm{këto} \mathrm{raste} \mathrm{fatlume,} \mathrm{ku} \mathrm{vlerat} \mathrm{e} \mathrm{prodhuara} \mathrm{nga} \mathrm{një} \mathrm{insitucion} \mathrm{(bile}$ edhe vlerat hipotetike që synohej të prodhonte ai institucion, qysh në lindje të tij) kanë mundësuar fillesat e mitit mbi të, është Shkolla Normale e Elbasanit, që i hapi dyert e saj më 1 dhjetor 1909.

Por në kohët moderne, përballë sfidës së modelit që na shoqëron në përpjekjet për t'u përsosur e shkuar përpara, ndërsa çmitizojmë e mitizojmë në vijimësi vlera, kemi nevojë, në radhë të parë, për ato tregues arketipore të asaj tradite të mitizuar që kanë bartur suksesin; ndaj institucione të tilla si Normalja sërish vijnë në vëmendje, sërish mund të na shërbejnë në këtë përballje.

Sado entuziastë qofshim, edhe vetë miti mbetet pa ndikim, kur nuk arrijmë të vërejmë treguesit përmbajtësorë të përvijuar në atë traditë; për më tepër, kur vëren që është mitizuar ngjarja, pa aktorë; është mitizuar vlera, pa prodhuesit e saj; është mitizuar institucioni, pa brendinë, pa kahjet dhe synimet, bile është mitizuar institucioni edhe pa historinë e tij.

Ndaj është mision intelektual t’i ndriçojmë ato vlera, t'u mundësojmë atyre të na ndihmojnë në sfidën e modelit që kërkojmë të përvijojmë në këto kohë moderne të zhvillimit të arsimit; për më tepër, kur vëren që shtërngata ideologiike e gjysmës së dytë të shekullit XX në mjedin shqiptar e pati larguar,

1 Cituar nga «Mythe», Le Petit Robert, 1, Dictionnaire Le Robert, 1990, faqe, 1251. 


\section{Albanon}

\section{Revistë kulturore}

mpakur dhe shurdhuar zërin e profesoratit të Normales, që pati formësuar një komunitetit diskursiv që po bënte histori në arsimin shqiptar. ${ }^{2}$

Miti për Normalen ishte rrjedhojë jo vetëm e receptimeve të vlerave që lidheshin me funksionet arsimore e edukative të institucionit, por sidomos e receptimit të intensitetit dhe përmasave të vlerave që i tejkalojnë së tepërmi ato funksione. Pikërisht zgjerimi i përmasave dhe thellimi i funksioneve mundëson mitin.

Përgjithësisht shkollat normale në Europë, por edhe në SHBA, kanë lindur si shkolla publike, popullore, me një funksion të përcaktuar, rrjedhojë të ndryshimeve të mëdha shoqërore dhe si insitucione që do të kryenin një funksion tepër human: "të restauronin mendjen njerëzore". ${ }^{3}$

Duke qenë edhe ky një funksion i shenjtë e fisnik, shkollat e kësaj natyre përvijuan historinë e tyre, duke lënë gjurmë në zhvillimin e sistemeve arsimore të vendeve përkatëse, duke ndikuar dhe duke u ndikuar reciprokisht edhe nga njëra-tjetra, nga njëri vend te tjetri, nga njëra hapësirë në tjetrën.

Normalja e Elbasanit, si shkollë e atij tipi, i synoi ata parametra të shkollave europiane e ballkanike, por qysh në fillesë ishte krijuar me një gamë shumë më të gjerë funksionesh dhe synimesh. Mjedisi shqiptar, realiteti shqiptar i gjysmës së parë të shekullit XX ndikuan që ky institucion të ishte akoma më polivalent, më i shumëvlershëm: do të ishte njëkohësisht shkollë popullore dhe elitare; do të ishte njëkohësisht mundësi shkollimi për nivele të caktuara moshore, por edhe akademi, institut pedagogjik apo universitet për atë kohë; do të ishte institucion mësimor, por edhe instituti kërkimor në fushën e psiko-pedagogjisë dhe shkencave të zbatuara; do të zbatonte teoritë psikopedagogjike dhe njohuritë e disiplinave të shkencave të ndryshme por do të kërkonte e ndërmerrte edhe studime në këto fusha në terrenin shqiptar; do të sillte mendimin shkencor botëror te nxënësit a studentët, por do të përvijonte edhe stilin shkencor dhe terminologjinë shkencore të shqipes në ato fusha, duke bërë që autorët më në zë botërorë të flisnin edhe shqip; do të nxiste aftësitë krijuese e kërkimore shkencore të nxënësve a studentëve, por do t'u jepte atyre edhe tribunën ku ata do të përfaqësoheshin, revistën e tyre; do t'i formonte studentët e vet me dije shkencore, por edhe do t' i tërhiqte pandërprerë pranë kësaj vatre, edhe pse ata shkëlqyen në institutet

2 Për shurdhimin a mpakjen e zërit të komunitetit diskursiv në Normalen e viteve 3040 të shekullit të kaluar, shih më gjerë T. Plangarica «Vlera të rishfaqura», Onufri, 2019, faqe 100-116.

3 Shih më gjerë për këtë argument, shkrimin «Elbasani e mbajti Normalen pse e deshi (duke njohur një traditë...)» në «Vlera të rishfaqura», faqe 19-37. 
a universitetet e Europës dhe iu kërkua të punonin dhe lektoronin atje; do të mëkonte patriotizmin, ndjenjën e atdhedashurisë e lirisë dhe do të sillte kontribut konkret më shumë se çdo institucion tjetër arsimor në ndihmë të kombit; do të synonte restaurimin e mendjeve të njerëzve dhe do të formonte konkretisht elementet e organizimit dhe funksionimit të institucioneve apo strukturave të shoqërise civile (shoqatat e ndryshme); do t'u krijonte hapësirat më të mëdha mësimit të kulturës dhe qytetërimit shqiptar, por do t'u jepte vendin e duhur edhe mësimit të kulturës dhe gjuhëve të vendeve prej të cilave kishin ç'të mësonin; do të synonte formimin sa më të plotë teorik të studentëve, por, në të njëjtën kohë, e njëjta rëndësi do t’u kushtohej mësimdhënies si art, aktivitetit praktik dhe didaktikës së çdo lënde; do të hartonte planet dhe programet mësimore, të cilat ishin të krahasueshme me ato ballkanike, por edhe europiane dhe, njëkohësisht, në të shumtën e lëndëve dhe disiplinave do të hartoheshin dhe tekstet përkatëse; do të theksohej rëndësia e eksperimentimit pedagogjik dhe, njëkohësisht, do të hapej dhe funksiononte duke prodhuar vlera edhe shkolla ushtrimore pranë Normales. ${ }^{4}$

Nëse individët, mësuesit, kërkuesit e shkencëtarët përfaqësojnë edhe komunitetin ku punojnë e eksperimentojnë, atëherë, me gjuhën e fakteve mund të pohojmë se ky institucion ka vënë gurë themeltarë në disa fusha të mendimit shkencor shqiptar në ato fillime të vështira të tij, si në fushën e psiko-pedagogjisë, gjuhësisë së zbatuar, gjeografisë, historisë, mësimdhënies së matematikës, fizikës, gjuhëve të huaja, leximit letrar, lëndëve të edukimit fizik e artistik etj.

E pra, në këto kushte, prandaj pohojmë se ky institucion nuk ishte vetëm një shkollë e mesme, por njëkohësisht një akademi, një institut, një universitet, një editor, një komunitet atdhetar e patriotik... një vlerë e paçmuar kombëtare. Ishte ky koncept që mbizotëroi qysh në kohën kur ai u themelua, ndaj, krahas me themelimin e institucionit, pati fillesat edhe miti për të.

Në kohët moderne mitet bashkëshoqërojnë kulturën dhe moralin, por si shtysa për të krijuar realitete funksionale. Në këta dhjetëvjeçarë të parë të shekullit XXI, ku dukuria e mitizimit dhe çmitizimit na bashkëshoqëron edhe për arsye ekstrakulturore dhe esktraetike, do të ishte e logjikshme që miti mbi Normalen të na shërbente si shtysë për të ndërtuar dhe përvijuar realitete të reja. Nga ky këndvështrim mitet ofrojnë vlera, kur ndihmojnë për

4 Shih më gjerë për secilin tregues të këtij institucioni, argumentimet dhe të dhënat e sjella në «Vlera të shfaqura», faqe 38-99. 


\section{Albanon}

\section{Revistë kulturore}

realitete të reja. Por, padyshim, ato ofrojnë frymë dhe jo gjedhe të gatshme, ofrojnë vlera morale, por jo dije dhe njohuri të zbatueshme, ofrojnë edhe përvojë, por jo klishe dhe shabllone që mund të përdoren drejtpërdrejt.

Pikërisht nga ky këndvështrim miti i Normales nxit/duhet të nxisë ndërgjegjen intelektuale të aktorëve të sotëm elbasanas, kujtoj, të cilët priren/duhet të priren që të kapin dhe përvijojnë frymën e vazhdimësisë.

Për më tepër miti i Normales u shoqërua me mitizimin e mjedisit në të cilin ky institucion lindi e u zhvillua. Ky mit bashkëshoqëroi e mitizoi po ashtu edhe frymën e vullnetin e familjeve elbasanase për arsim dhe projeksionin për të mëkuar arsimim, që, duke iu bashkëngjitur mitit të institucionit me të cilin qe përftuar, përmes një raporti metonimik tejet shprehës, përftoi pohimin tejet domethënës : Elbasani-djepi i arsimit kombëtar.

Është i motivuar ky pohim madhor, ndërsa njihesh me devotshmërinë e elbasanasve ndaj Normales, "që e mbajtën, pse e deshën" dhe pse e deshën, iu dhanë, iu përkushtuan asaj me të gjitha energjitë, duke pranuar heshturazi e fisnikërisht çdo sakrificë që i kërkonte përmbushja e misionit që ai institucion kultivonte. Me dëshirën e pasionin jo të zakontë për t’i shkolluar fëmijët në atë institucion, familjet elbasanase kompensuan me bujari shumë prej nevojave të ngutshme për mësimdhënës në të tëra trevat shqiptare. Ishte një përkushtim i këtyre familjeve që cënoi normalitetin e funksionimit të natyrshëm familjar, projektimin e natyrshëm të ardhmërisë së fëmijëve, duke ndezur kësisoj pasione të fokusuara te mësimdhënia e arsimimi. Është e pakrahasueshme me mjediset sociale në qytetet e tjera ky qëndrim fatlum që Normalja i mundësoi atij mjedisi qytetar, që e lidhi funksionimin e tij me një mision të tillë madhor. Është një sakrificë që do ta përngjasonim me dhurimin e gjakut që ai mjedis bënte për shëndoshjen e trupit të shoqërisë shqiptare në të gjithë hapësirën shqiptare, në Shqipëri, Kosovë e Maqedoni. Janë energji sociale dhe intelektuale që u përqendruan në atë mision, që e parakuptonte këtë sakrificë, ndërkohë që po të njëjtat energji mund të krijonin tjetër komoditet social e intelektual, nëse do të shpërnguleshin edhe në fusha të tjera të veprimtarisë intelektuale.

Si produkt i atij kontributi ishte mirënjohja kombëtare ndaj atyre misonarëve. Riqasja në interpretim ndaj këtij përkushtimi, ndaj kësaj sakrifice është gjithsesi një homazh dhe shenjë mirënjohjeje që duhet t’ia blatojmë pa mëdyshje e në vijimësi kësaj vlere të këtij komuniteti.

Gjithsesi shekulli i 21-të ka nevojë për guxim intelektual, hapësira të reja intelektuale e veprimi, individë të formuar që i përballojnë sfidat, sepse për 
to investon shoqëria përmes arsimimit të vërtetë; ka nevojë, gjithashtu, për shoqërinë e emancipuar, që shkon pëpara, sepse për të investojnë individë të arsimuar.

Nëse miti për Normalen gjëllin duke u shfaqur e rishfaqur, duke u përtërirë e ripërtërirë në këtë truall që e lindi së bashku me vetë institucionin, kjo do të thotë se ky truall vijon të jetë kontekst i atyre vlerave dhe kontributeve që lindin e zhvillohen për qëllime e funksione sublime, siç është arsimimi, prirja drejt zhvillimit, kultivimit të ndjenjës kombëtare, si dhe universalizmit. Për më tepër, kjo do të thotë se ky kontekst dhe ky realitet parakuptojnë dhe kërkojnë vlera dhe realitete të reja në fushën e arsimimit, përvijimi i të cilave do të na bënte fatlumë, nëse brezat e ardhshëm do t'i perceptonin me aureolën metaforike të mitit.

Hera-herës epokat kërkojnë çmitizimin a shenjtërimin e mitit, por herë të tjera edhe

riaktualizimin e tij. Në këtë distancë kohore, në këtë 110-vjetor të themelimit të këtij institucioni, riaktualizimi i mitit të Normales përbën vlerë, pasi edhe një herë na kujton të receptojmë me kujdes lajmëtarët e së ardhmes, fillesat e mitit për Normalen.

Por, nëse çdo kohë ka të përvijuar realitetet konkrete dhe prirjen drejt së ardhmes, lajmëtaret që vijnë prej së ardhmes dhe duhen perceptuar si të tillë, padyshim që janë jo të njëjtë. Suksesi në këtë përzgjedhje dhe perceptim mund të jetë fillesë e aureolës së mitit në përhershmëri.

Aktorët e sotëm në institucionet që e konsiderojnë veten vazhduese të traditës së formësuar nga Normalja bartin edhe një tjetër përgjegjësi - çuarjen më tej të traditës së përftuar nga ai institucion; përballen edhe me një tjetër sfidë të kuptojnë mesazhet që vijnë prej së ardhmes, ashtu si komuniteti diskursiv i Normales i receptoi ato dhe i parapriu zhvillimeve.

Është sfidë që e parakupton misioni i institucioneve që përgatisin mësues e studiues të arsimit, institucione që, duke ndërgjegjësuar kërkesat e së ardhmes, përgatisin njëherazi edhe qytetarët e së ardhmes. 